\title{
Model of Determining the Location of a Junior High School Building
}

\author{
$1^{\text {st }}$ Daryono \\ Department of Geography Education \\ Faculty of Social Sciences and Law \\ Universitas Negeri Surabaya \\ Surabaya, Indonesia \\ daryono@unesa.ac.id
}

\author{
$2^{\text {nd }}$ Ketut Prasetyo \\ Department of Geography Education \\ Faculty of Social Sciences and Law \\ Universitas Negeri Surabaya \\ Surabaya, Indonesia email: \\ ketutprasetyo@unesa.ac.id
}

\author{
$3^{\text {rd }}$ Sukma Perdana Prasetya \\ Department of Geography Education \\ Faculty of Social Sciences and Law \\ Universitas Negeri Surabaya \\ Surabaya, Indonesia \\ sukmaperdana@unesa.ac.id
}

\begin{abstract}
The construction of a new junior high school unit is one of the priority programs for the implementation of 9 Year Compulsory Education. However, until now there is no guideline/model that can be used as a reference to determine the location of a junior high school in a region. This research seeks to develop a model that can be used as an alternative that can be used for reference in determining the location of the building of a junior high school in an area. Establish a model of SMP building location determination by using geographic information system (GIS) and global positioning system.The most important factor in formulating the model of determining the location of the SMP building in Nganjuk District, Sawahan District, and Rejoso District is accessibility. Differences in the form of expression of spatial settlements also determine the difference of input elements and processes needed to compile the model of determining the location of the building SMP.
\end{abstract}

Keywords-location, School, GIS

\section{INTRODUCTION}

Compulsory study of 9 years of basic education in Indonesia to date its implementation still requires refinement. The challenges and obstacles to the implementation of education in Indonesia are for the first level of the advanced or advanced level, among others, hampered by socioeconomic factors and geographical factors. One of the strategies of education development policy in Indonesia is to expand and state the opportunity to obtain quality education for all Indonesian people [1]. In the framework of the implementation of 9 Year Compulsory Development of new school unit of junior high school is one of the priority programs.

The junior high school building is one of the public service places that ideally should be easily accessible by the children who need the facility. The ease of reaching the junior high school building is closely related to the level of accessibility between the school building and the student's residence, which includes physical distance, travel time.

Topographic conditions will greatly determine the pattern of population settlements, transportation routes, the possibility of public transport availability, the availability of suitable space for school buildings, etc. [2]. The existence of a school building as one of the forms of public facilities should be placed in an easily accessible location by students expected to attend school buildings. Therefore the location of the school building should be located in the most accessible location by the students in accordance with the characteristics of each region.

The purpose of this study are as follows: (1) Knowing the accessibility of accessibility / ease of physical distance, travel time, and easiness to obtain the means of transportation from student's residence to the school building according to junior high school students; (2) To know accessibility assessment / ease of physical distance, travel time, and ease of obtaining transportation from student's residence to school building according to principal's opinion and school committee; (3) Establish a model of SMP building location determination by using geographic information system (GIS) and global positioning system (GPS)[3].

\section{METHOD}

The research design of this research is arranged as follows.

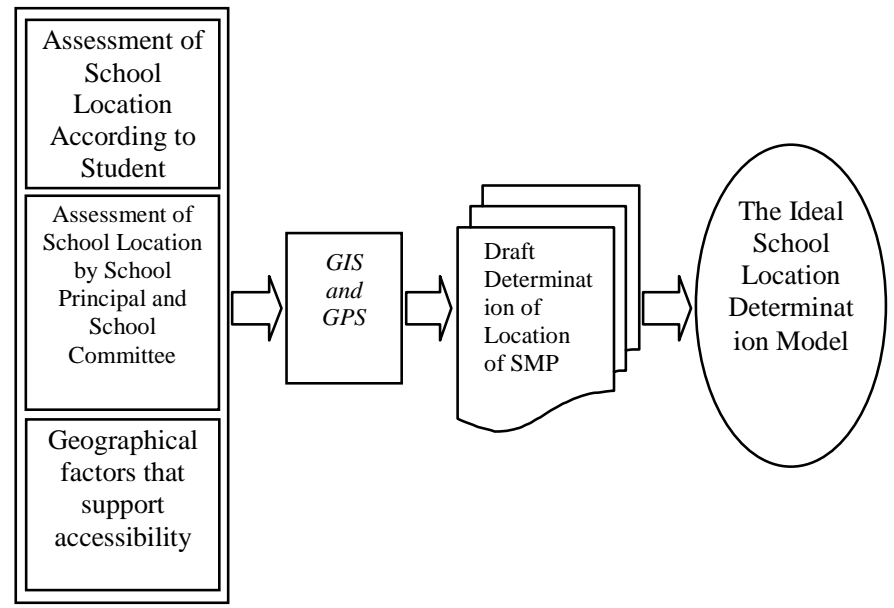

Figure 1. Research Design

Nganjuk district was chosen as a research area because it has a very diverse topography. Some of its territory there is a rough, moderate, and flat topography. Thus, the model is expected to be applied/applied to a region with a diverse topography.

The population of this study there are two kinds, namely population associated with space, and the population associated with the junior high school (SMP). Population- 
related to space is all districts in Nganjuk Subdistrict which consists of 19 Subdistricts, while the population of SMP is all the SMP Negeri that exist in Nganjuk regency, which is 50 units. A sampling of spaces with school samples are interrelated, meaning that the SMPN selected as the sample is the school located in the selected region as the sample.

The sample of the research was taken purposively on the basis of the main consideration is the topography. As mentioned above, namely that the topography in Nganjuk can be divided into three, ie there are areas with rough, moderate, and flat topography. On that basis, in this study were taken three districts whose topography really reflects the characteristics of each topographical state. Based on this matter, Sawahan District is chosen to represent rough-walled territory, Rejoso District represents moderate-paced regions, and Nganjuk district represents flat-topped.

All SMP in Sawahan District (as many as two) is taken as samples because although both are located in rough-walled areas, the locations of the two schools are relatively far apart. All state junior high schools in Rejoso sub-district (three) are also taken as samples because of the topography in this area which varies and is the most widespread area in Nganjuk regency (151,66 ha). Because of its uniform topography, which is flat with the most narrow area in Nganjuk Regency (22.59 ha), then from seven SMP Negeri in Nganjuk District only two samples taken from SMP Negeri, SMP Negeri I representing schools in the city center, and junior high Country VI represents schools in the suburbs.

The entire principal of the sample junior high school as a whole is made a respondent, for school committee respondents, each school is represented by 3 members of the school committee, and for student respondents, each school is taken one class as a sample. Purposively, it is determined that the sample is a 2nd grader on the grounds that the student has been in school for a year so that they feel that they have enough difficulty or easiness to go to school from their place of residence. The researcher selects one of the classes by drawing.

Table 1. THE NUMBER OF RESPONDENTS IN THREE THE SAMPLE

\begin{tabular}{|c|l|c|c|c|}
\hline No & Districts & Headmaster & School Committee & Student \\
\hline 1. & Sawahan & 2 & 6 & 81 \\
\hline 2. & Rejoso & 3 & 9 & 126 \\
\hline 3. & Nganjuk & 2 & 6 & 84 \\
\hline
\end{tabular}

In accordance with the required data characteristics, data collection techniques used in this study are 1) questionnaire, used to collect data related to the students' assessment of the location of the SMP building, 2) focus group discussion (FGD), used to collect data related to the assessment of school principals and school committees on the location of the SMP building, and implemented in each District; 3) documentation, used to collect data related to the map and to collect data on the general description of the research area and data on education generally in the research area, 4) observation, used to confirm the location of a place on the map with the actual location in the field, the tool used is GPS.

\section{RESULTS AND DISCUSSION}

A. Result

1). Assessment Distance Between Student Residence and Junior High School Building

The results of the survey of distance from the student's residence to the junior high school in rough, moderate, and sloping terrain shown in tables 2,3 , and 4 .

Table 2. STUDENT RESPONDENT'S RESIDENTIAL SPACING TO JUNIOR HIGH SCHOOL IN ROUGH-WALLED AREA (SAWAHAN DISTRICT)

\begin{tabular}{|c|c|c|c|}
\hline No. & Distance & amount & Percentage \\
\hline 1. & $0,00-2,00 \mathrm{Km}$ & 32 & 43,84 \\
\hline 2. & $2,01-3,00 \mathrm{Km}$ & 6 & 8,22 \\
\hline 3. & $3,01-5,00 \mathrm{Km}$ & 17 & 23,29 \\
\hline 4. & $>5,00 \mathrm{Km}$ & 18 & 24,66 \\
\hline \multicolumn{2}{|c|}{ Total Answering } & 73 & $100 \%$ \\
\hline
\end{tabular}
Source: primary data analysis

It appears that almost a quarter of respondents in roughwalled terrain have to travel more than $5.25 \times 2$ kilometers (going-to-school) to school.

Table 3. DISTANCE OF RESPONDENTS FROM STUDENTS TO JUNIOR HIGH SCHOOL BUILDING IN MODERATELY MODIFIED AREA (DISTRICT REJOSO)

\begin{tabular}{|c|c|c|c|}
\hline No & Distance & amount & Percentage \\
\hline 1 & $0,00-2,00 \mathrm{Km}$ & 64 & 51,20 \\
\hline 2 & $2,01-3,00 \mathrm{Km}$ & 30 & 24,00 \\
\hline 3 & $3,01-5,00 \mathrm{Km}$ & 30 & 24,00 \\
\hline 4 & $>5,00 \mathrm{Km}$ & 1 & 0,48 \\
\hline \multicolumn{2}{|c|}{ Total Answering } & 125 & $100 \%$ \\
\hline
\end{tabular}

Source: primary data analysis

Compared to respondents in rough terrain, respondents in moderate-paced areas (Rejoso) had to travel more than 5.25 $\mathrm{x} 2$ kilometers (commuter) to school every day, fewer.

Table 4. DISTANCE OF STUDENT RESIDENCE TO JUNIOR HIGH SCHOOL IN FLAT FLAT AREA (NGANJUK DISTRICT)

\begin{tabular}{|c|c|c|c|}
\hline No & Distance & amount & Percentage \\
\hline 1 & $0,00-2,00 \mathrm{Km}$ & 33 & 39,76 \\
\hline 2 & $2,01-3,00 \mathrm{Km}$ & 11 & 13,25 \\
\hline 3 & $3,01-5,00 \mathrm{Km}$ & 19 & 22,89 \\
\hline 4 & $>5,00 \mathrm{Km}$ & 20 & 22,10 \\
\hline \multicolumn{4}{|c|}{ Total Answering } \\
\hline Catatan: jumlah total responden adalah 84, dan hanya 1 responden atau \\
1,20\% yang tidak memberikan jawaban \\
Source: primary data analysis
\end{tabular}

Compared to respondents in rough and moderate-ontopic rough terrain, respondents in flat-topped regions that had to travel more than 5.25 kilometers to school every day were almost the same proportion as respondents in Sawahan and much larger than the proportion of respondents with the same distance at a moderate-paced region (Rejoso).

2). Travel Time Between Student Residence and Junior High School Building

The results of the survey of travel time from student residence to junior high school in rough, moderate, and steep terrain are shown in tables 5, 6, and 7. 
Table 5. TRAVEL TIME FROM STUDENT RESPONDENT'S RESIDENCE TO JUNIOR HIGH SCHOOL IN ROUGHWALLED AREA (SAWAHAN DISTRICT)

\begin{tabular}{|c|c|c|c|c|c|c|}
\hline No & $\begin{array}{c}\text { Traveling } \\
\text { time }\end{array}$ & Student & Percent & $\begin{array}{l}\text { Fastest } \\
\text { (Minute) }\end{array}$ & $\begin{array}{l}\text { Oldest } \\
\text { (Minute) }\end{array}$ & $\begin{array}{l}\text { Average } \\
\text { (Minute) }\end{array}$ \\
\hline 1 & walking & 35 & 42,31 & 1 & 120 & 45,55 \\
\hline 2 & Bike & 9 & 11,11 & 5 & 60 & 38,89 \\
\hline 3 & Motorcycle & 12 & 14,81 & 10 & 30 & 18,75 \\
\hline 4 & $\begin{array}{l}\text { Motor } \\
\text { vehicle }\end{array}$ & 13 & 16,06 & 3 & 30 & 13,46 \\
\hline 5 & Shuttle & 12 & 14,81 & 10 & 60 & 23,75 \\
\hline \multicolumn{2}{|r|}{ amount } & 81 & 100,00 & & & \\
\hline
\end{tabular}

Source: primary data analysis

Respondents with the fastest travel time in Sawahan District were using motor vehicles (average 2 x 13.46 minutes), and then sequentially from the fastest average to the longest average by motorcycle respondents $(2 \times 18.75$ minutes), picked up ( 2 x 23.75 minutes), cycled $(2 \times 38.89$ minutes), and on foot ( $2 \times 45.55$ minutes). Most respondents in District Rejoso travel to school by bicycle.

Table 6. TRAVEL TIME FROM STUDENT RESIDENCE TO JUNIOR HIGH SCHOOL IN MODERATE-PACED AREA (REJOSO DISTRICT)

\begin{tabular}{|c|c|c|c|c|c|c|}
\hline No & $\begin{array}{c}\text { Traveling } \\
\text { time }\end{array}$ & Student & Percent & $\begin{array}{l}\text { Fastest } \\
\text { (Minute) }\end{array}$ & $\begin{array}{l}\text { Oldest } \\
\text { (Minute) }\end{array}$ & $\begin{array}{l}\text { Average } \\
\text { (Minute) }\end{array}$ \\
\hline 1 & walking & 21 & 16,67 & 2 & 30 & 9,00 \\
\hline 2 & bike & 103 & 81,75 & 5 & 45 & 18,19 \\
\hline 3 & Motorcycle & 1 & 0,79 & 20 & 20 & 20,00 \\
\hline 4 & $\begin{array}{l}\text { Motor } \\
\text { vehicle }\end{array}$ & 1 & 0,79 & 5 & 5 & 5,00 \\
\hline \multicolumn{2}{|c|}{ amount } & 84 & 100,00 & & & \\
\hline
\end{tabular}

The fastest respondents in Rejoso District were respondents who were transported (5.00 minutes), and then from the fastest average to the longest reached by the respondents on foot (9 minutes), cycling (18.19 minutes), and motor vehicle (20.00 minutes).

Table 7 TRAVEL TIME FROM STUDENT RESIDENCE TO JUNIOR HIGH SCHOOL BUILDING IN FLAT FLAT AREA (NGANJUK DISTRICT)

\begin{tabular}{|c|c|c|c|c|c|c|}
\hline No & $\begin{array}{c}\text { Traveling } \\
\text { time }\end{array}$ & Student & Percent & $\begin{array}{c}\text { Fastest } \\
\text { (Minute) }\end{array}$ & \begin{tabular}{|l|} 
Oldest \\
(Minute)
\end{tabular} & $\begin{array}{l}\text { Average } \\
\text { (Minute) }\end{array}$ \\
\hline 1 & walking & 6 & 7,14 & 5 & 30 & 15 \\
\hline 2 & bike & 54 & 64,29 & 5 & 60 & 21,48 \\
\hline 3 & Motorcycle & 6 & 7,14 & 10 & 20 & 15,33 \\
\hline 4 & $\begin{array}{l}\text { Motor } \\
\text { vehicle }\end{array}$ & 9 & 10,71 & 5 & 60 & 26,67 \\
\hline 5 & Shuttle & 9 & 10,71 & 2,5 & 15 & 9,72 \\
\hline \multicolumn{2}{|c|}{ amount } & 84 & 100,00 & & & \\
\hline
\end{tabular}

Source: primary data analysis

Based on the average traveling time of the respondents going to and from school according to the way they travel in Nganjuk District, then the fastest average of the respondents who transferred (9.72 minutes), and then sequentially from the fastest average to the most average (15 minutes), motorcycling (15.33 minutes), cycling (21.48 minutes), and motorized driving (26.67 minutes).

3). Public transport between the Student Residence and Junior High School Building

Specific respondents who walk to the school to express the reasons as shown in the following table.
Table 8. REASONS OF RESPONDENTS WALKING TO SCHOOL

\begin{tabular}{|c|c|c|c|c|}
\hline No & Area & Walking to School considerations & amount & Percent \\
\hline \multirow{4}{*}{1} & \multirow{4}{*}{$\begin{array}{l}\text { Sawahan } \\
\text { (Slopes) }\end{array}$} & Rarely passed by public transport & 13 & 40,7 \\
\hline & & There are no public transport costs & 9 & 28,1 \\
\hline & & Distance to school is too close & 10 & 32,3 \\
\hline & & Total students walk & 32 & 100,0 \\
\hline \multirow{4}{*}{2} & \multirow{4}{*}{$\begin{array}{c}\text { Rejoso } \\
\text { (Moderate } \\
\text { Slope) }\end{array}$} & Rarely passed by public transport & 1 & 4,5 \\
\hline & & There are no public transport costs & 1 & 4,5 \\
\hline & & Distance to school is too close & 20 & 91,0 \\
\hline & & Total students walk & 22 & 100,0 \\
\hline \multirow{3}{*}{3} & \multirow{3}{*}{$\begin{array}{l}\text { Nganjuk } \\
\text { (Flat } \\
\text { slope) }\end{array}$} & There are no public transport costs & 1 & 14,3 \\
\hline & & Distance to school is too close & 6 & 85,7 \\
\hline & & Total students walk & 7 & 100,0 \\
\hline
\end{tabular}

Source: primary data analysis

Sawahan District is an area dominated by steep slopes. The reason for the difficulty of accessing public transport is more expressed by the respondents who walk, reaching 67.7 percent, consisting of the location of the residence is rarely passed by public vehicles expressed by 13 students or 40.7 percent of pedestrian respondents, and the remaining 9 students or 28.1 percent of pedestrian respondents stated the reason for the absence of fees for public transport. Thus, it can be seen that in the District Sawahan there are serious problems for students to access public transport as a way of traveling from his residence to school.

Rejoso District is an area with moderate topography. Most of the pedestrian pedestrians' reasons for not using public transport are the distance to school considerations that are too close, which is stated by 20 students or 91.0 pedestrian respondents. Thus, the way students in District Rejoso travel from his residence to school by accessing public transport no problem.

Nganjuk District is a flat topography area. Only 1 student or 14.3 percent of pedestrian respondents in Nganjuk District stated the reason for difficulty accessing public transportation, ie no cost for public transportation. Most of the reasons for pedestrian respondents not to use public transportation in Nganjuk District is the consideration of the distance to the school that is too close, which is expressed by 6 students or 85.7 percent of pedestrian respondents. Thus, it can be seen that in the District Nganjuk, the way students travel from their homes to school by accessing public transport no problem.

Table 9. DISTANCE OF RESIDENCE TO SCHOOL BUILDING (Km)

\begin{tabular}{|l|c|c|c|c|}
\hline \multirow{2}{*}{\multicolumn{1}{c|}{ District }} & \multirow{2}{*}{$\mathrm{N}$} & \multicolumn{3}{c|}{ Distance from Residence to School } \\
\cline { 3 - 5 } & & Terdekat & Terjauh & Mean \\
\hline Nganjuk & 83 & 0,10 & 17,0 & 4,03614 \\
\hline Rejoso & 125 & 0,05 & 7,0 & 2,29024 \\
\hline Sawahan & 73 & $<0,05$ & 15,0 & 3,63377 \\
\hline Total & 281 & $<0,05$ & 17,0 & 3,15496 \\
\hline
\end{tabular}

Table 10. THE FURTHEST DISTANCE NOT INCRIMINATING STUDENTS TO SCHOOL

\begin{tabular}{|l|c|c|c|c|}
\hline \multirow{2}{*}{ District } & \multirow{2}{*}{$\mathrm{N}$} & \multicolumn{3}{|c|}{$\begin{array}{c}\text { The Furthest Distance that Doesn't } \\
\text { Burden to School (kilometer) }\end{array}$} \\
\cline { 3 - 5 } & & Terdekat & Terjauh & Mean \\
\hline Nganjuk & 13 & 1,00 & 12,00 & 4,4231 \\
\hline Rejoso & 47 & 0,50 & 2,50 & 1,5532 \\
\hline Sawahan & 46 & 0,50 & 1,50 & 0,9891 \\
\hline Total & 106 & 0,50 & 12,00 & 1,6604 \\
\hline
\end{tabular}


Apparently, compared to Nganjuk district with ramps and Rejoso bertopografi moderate bertopografi, respondents in District Sawahan has the average mileage that is not burdensome to the shortest school, which is 0.99 kilometers. Thus compared in Nganjuk and Rejoso Districts, respondents in District Sawahan are the respondents most in need of the highest accessibility in determining the location of the junior high school building.

4). Junior High School Accessibility Assessment by School Principals and School Committees

School committees and principals in District Sawahan agree that factors in determining school buildings based on their priority scale are 1) easy to reach, 2) a supportive community environment, 3) away from the crowd, 4) not prone to disasters.

School committees and headmaster in Rejoso district agree that factors in determining school buildings based on their priority scale sequentially are 1) away from the crowd, 2) close to sports facilities, 3) availability of land allowing for expansion of school area, 4) appropriate with spatial plan, 5) location easy to reach by learners, 6) not in a dense residential area, 7) close to health facilities and infrastructure.

School committees and headmaster in Nganjuk district agree that factors in determining school buildings based on priority scale 1) transportation convenience, 2) supporting environmental conditions (safe, away from crowd and noise), 3 ) availability of clean water.

\section{5). Model Determination of Location Junior High School} Nganjuk District

Although in the 2nd, 3rd, 4th, and 5th zones in Nganjuk district it cannot be clearly distinguished, spatial expression tends to lead to concentric form, where zone 1 is the CBD developing in Nganjuk City Center. The model of determining the location of the SMP building in Nganjuk District with GIS and GPS with reference to the expression of the concentric ring can then be arranged in the following framework.

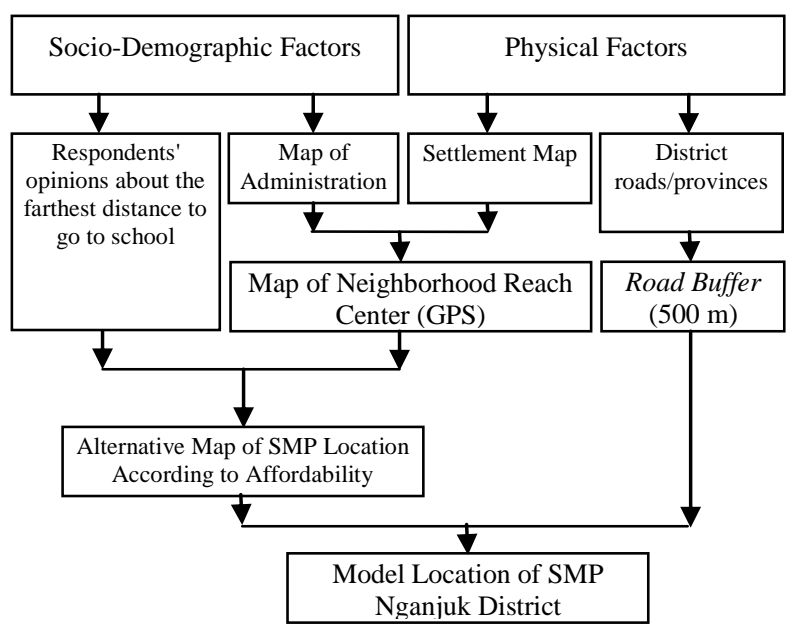

Figure 2. Modeling of SMP Building Location with GIS and GPS of Nganjuk District
The neglect of the existence of the river for the determination of the location model of the placement of the junior high school in Nganjuk District is done with the consideration that the rivers through the settlement area in Nganjuk district are only rivers and small channels. Here is a map generated from the above modeling.

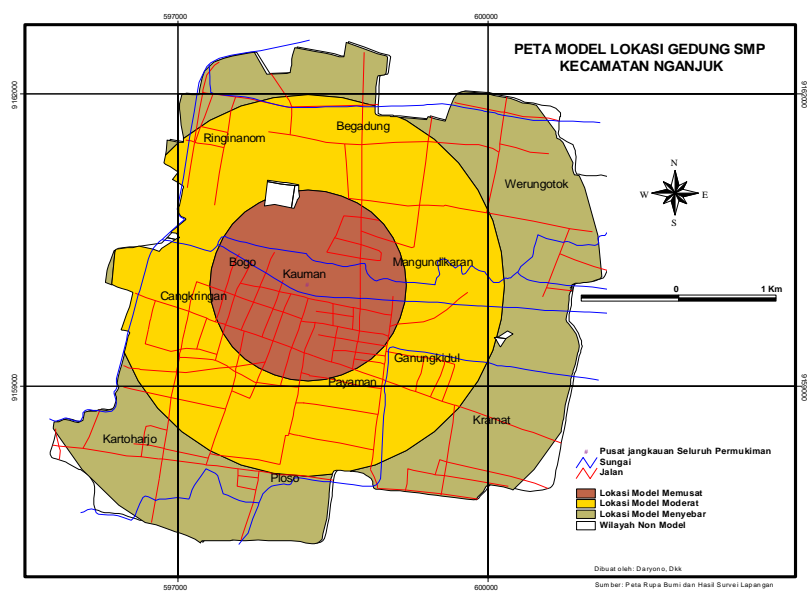

Figure 3. Map Result of Modeling of SMP Building Location with GIS and GPS of Nganjuk District

In fact, respondents did not question the distance to school in Nganjuk District. Supported by the administrative territory that is not too broad, then placing the location of the junior high school in the District Nganjuk actually does not require a certain direction. The direction centered, the direction moderate, and the direction spread, all three can be applied to choose the location of the junior high school in Nganjuk District.

6). Model Determination of Location Junior High School Rejoso District

The development of settlements in Rejoso District shows the form of expression of the spatial combination of scattered and concentric. This spatial combination form can start from a spatial use pattern that is distinctly differentiated by the topographic separator in Rejoso District. A regular pattern of settlement land use is more prominent in the south, while the northern regions are less regular. The more visible that the form of expression of settlement space in District Rejoso more dominant to the expression of concentric settlements in the south, and scattered in the north. 
Thus, the priority of location placement of the junior high school is more concerned with the residents of the southern part of the settlement because the population is relatively dense and the settlements tend to be organized although not too concentric.

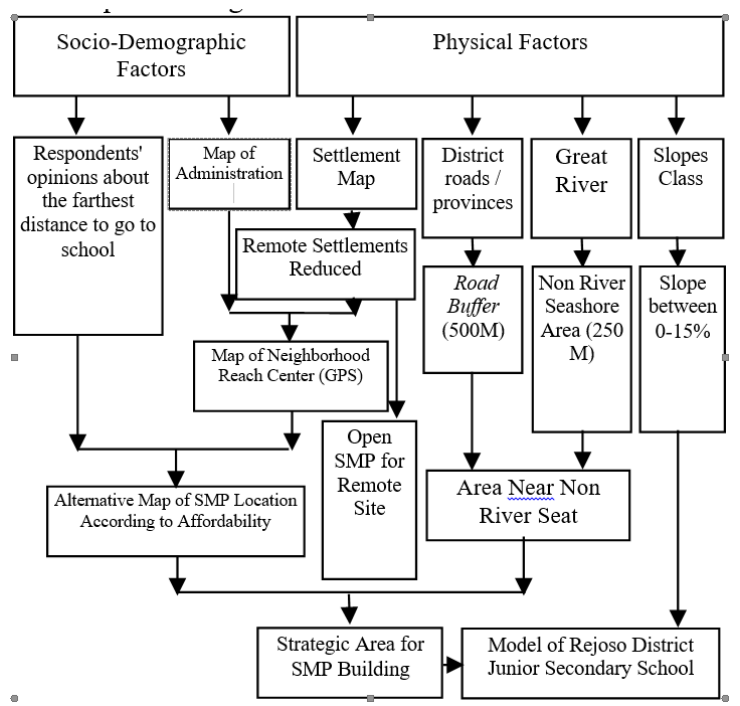

Figure 4. Modeling of SMP Building Location with GIS and GPS District of Rejoso

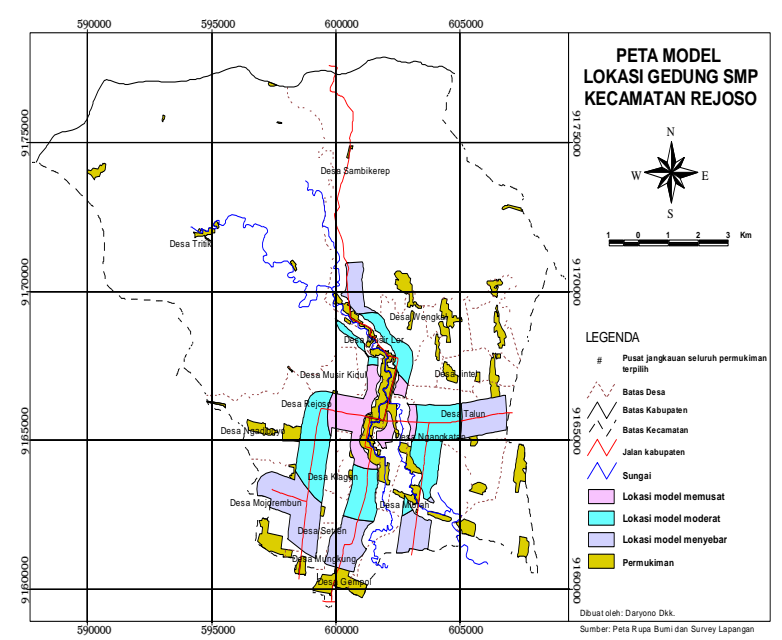

Figure 5. Map Result of Modeling of SMP Building Location with GIS and GPS of Rejoso District

A more precise location reference for the determination of the SMPS building based on the modeling results in District Rejoso is the combination of the model direction spread by the centered model. The scattered junior secondary school location enables equity, while centralized location guidance is needed to provide alternative schools for residents of certain settlements, so that residents may choose to obtain services from other schools not too far away. However, since it appears on the map of remote settlements, the junior secondary education services in these settlements can be provided through the procurement of open schools.

6). Model Determination of Location Junior High School Sawahan District

The development of settlements in Sawahan District shows the form of spatial expression. This two-dimensional form of spatial settlement expression appears irregular and is generally caused by the irregularities of the location of the dwelling land with the slope of a slope deserving to erect a building on it. Spatial settlement expression scattered in the case of Sawahan District shows that most of the settlements are in areas with good access roads, access to good water resources, and residential areas have a class of slopes that make it possible to erect buildings. Thus, the more visible that the form of expression of settlement spaces in the District of Sawahan more dominant to the expression of spatial settlements scattered.

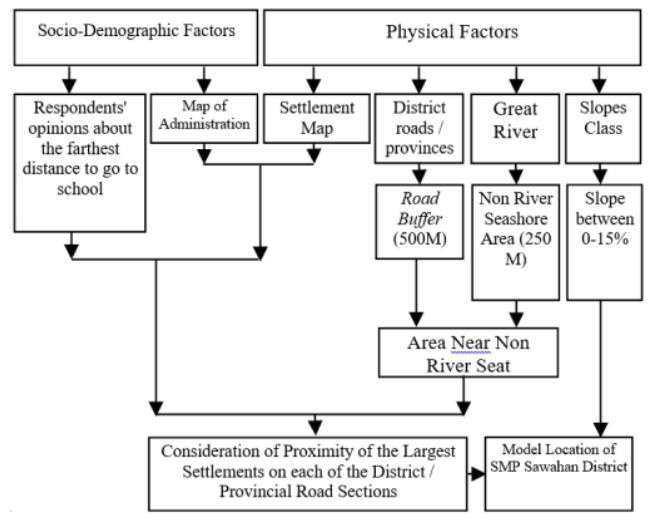

Figure 6. Modeling of SMP Building Location with GIS and GPS of Sawahan District

The pattern of spatial settlements in Sawahan District is almost the same as District Rejoso which has spatial expression scattered. The difference is, the expression of the spatial settlements in Sawahan District is an expression of spatial settlements scattered elongated. The elongated expression in Sawahan District is associated with the existence of a mutually aligned transportation route between a single longitudinal settlement path and other longitudinal settlement paths. The separators between these major transport routes are generally in the form of deep valleys. Therefore, the more appropriate location for the model of determining the junior high school building in District Sawahan needs to consider the expression of the spatial settlement that is scattered elongated.

Visible on the map of Figure 7 the existence of two areas whose location is appropriate to be built for the building of the junior high school. The first area is a priority area, whose boundaries are based on the presence of landing site units with proximity to the largest collection of settlements. The second area is the alternative location of the SMP building, which is chosen as the solution if the lands in the priority area are no longer available. Both areas are locations that have met the requirements of slopes, proximity to roads, and are not on sempai and river routes. Some areas in Sawahan District are located on flat slopes, the river valley is not deep, so the relationship between one settlement with other settlements can easily and relatively not require the high cost to be built a bridge. The development of settlements in the District of Sawahan is characterized by rivers that form deep 
and wide valleys. The existence of these rivers and valleys is a barrier and hinders access from one settlement to another.

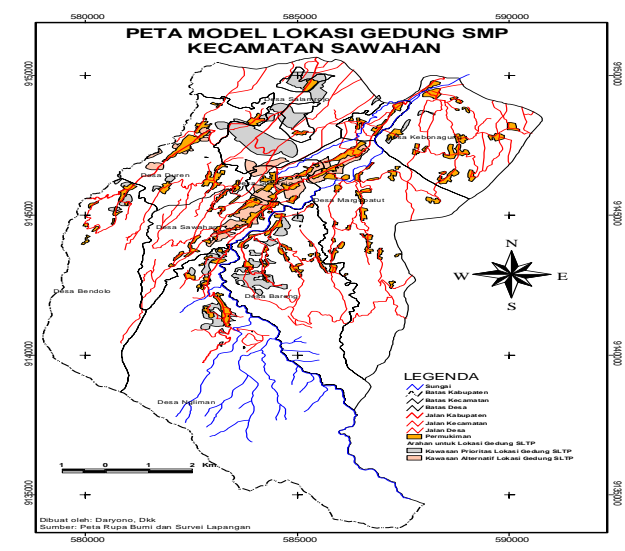

Figure 7. Map Result of Modeling of SMP Building Location with GIS and GPS of Sawahan District

\section{B. Discussion}

School buildings as one of the infrastructures of educational services should be easily accessible by the community as a recipient who needs services [4]. The key to determining the model of the location of the school building is the physical condition of the region, in this case, the topography characteristics [5],[6],[7]. The topography of a region will affect the spatial hue that exists in a region [8]. Topographic conditions, on the one hand, can support and on the other hand, can be a barrier to the development of a region's settlements [9], [10]. For example, flat topography in a region gives rise to settlement development in any direction, and on the contrary, rough-walled terrain causes the development of settlements to be heavily controlled by decent land availability. Such topography gives rise to the spatial expression, which is dispersed in accordance with the availability of suitable land for settlements. Another implication of the topography is to provide the hue of the transport network in a region, either from the aspect of density, the type of vehicle that is able to access, and the pattern of the road network [11], [12], [13]. In areas with rough topography, the existence of transportation networks is very limited. This limitation is solely controlled by slope conditions and the availability of land that allows for road network construction. As a result, the road network that formed a certain pattern and can only connect some settlements. On rough topography in general, rivers form deep and wide valleys that are the boundary and hinder access from one settlement to another. On the contrary, in flat areas, the river valleys are not deep so that the relationship between one settlement with another settlement can easily and relatively unnecessarily cost high to build a bridge [14]. Topographic conditions also greatly affect the availability of suitable land for school buildings. In areas with flat topography, it certainly provides more choice of land and the proper location for the building of the junior high school. In contrast, in areas with rough topography, the availability of space for junior high schools is very limited. This limitation is related to the conditions of the slopes in the area. In relation to the above, the preparation of the model determination of the location of the SMP building should be adjusted to the topographic characteristics of each region. Based on the spatial modeling done in this research, it appears that the determination of the priority location for the construction of the SMP building there is a difference in the determination of the supporting and limiting factors between the areas with rough topography (Sawahan), moderate topography (Rejoso), and the area with flat topography (Nganjuk). Determination of the location of SMP building in the area with rough topography, the factors that must be considered are settlement pattern, slope class, river border area, transportation line. In areas with moderate topography, the factors to be considered are settlement patterns, slope classes, boundary zones, transportation routes, while areas with flat topography, the factors that need to be considered are the settlement pattern, and transportation routes. Moderate topographic areas have a spatial expression with a combination pattern of settlement patterns in flat areas (concentric) and in rough terrain (scattered) [15]. Only, the scattered settlement patterns that exist in moderate topographic areas are different from the scattered settlement patterns that exist in harsh parsoned areas. In moderate topographic areas, the settlement pattern is scattered with small and scattered units of settlements with relative distances apart. Therefore, in moderate topography areas in addition to using models such as flat (concentric) areas, it is necessary to consider educational services for junior high school students in other forms specific to the region with a pattern of scattered settlements.

\section{CONCLUSION}

The most important factor in formulating the model of determining the location of the SMP building in Nganjuk District, Sawahan District, and Rejoso District is accessibility. Differences in the form of expression of spatial settlements also determine the difference of input elements and processes needed to compile the model of determining the location of the building SMP. Areas with flat topography provide more choice of land and suitable locations for the construction of junior high schools. In contrast, in areas with rough topography, the availability of space for junior high schools is very limited. This limitation is related to slope conditions in the area. The ideal distance between the residence and the junior high school in rough-walled terrain is no more than $1 \mathrm{~km}$, in moderate-to-narrow topographic areas over $1.5 \mathrm{~km}$, and in flat areas of no more than $4 \mathrm{~km}$. In relation to the location of school buildings, the principal considerations of school principals and school committees in rough-walled areas are within easy reach and supportive community environments, in moderate-paced regions, are far from crowded and close to sports facilities, whereas in flattopped regions is ease of transportation and supportive environmental conditions. Based on the model that has been compiled, the determination of the location of junior high schools in areas with rough topography and moderate, the factors that must be considered is the pattern of settlements, slope classes, riparian areas, transportation routes, while in areas with flat topography factors that must pay attention is the pattern of settlements, border zones, and transportation routes. 


\section{ACKNOWLEDGMENT}

This research can be completed with the assistance of Faculty of Social Sciences and Law, Universitas Negeri Surabaya through faculty policy funds in 2017.

\section{REFERENCES}

[1] B. P. P. N. (BAPPENAS), "Membangun Kesejahteraan Rakyat dan Ketahanan Budaya. Seminar Program Pembangunan Nasional,' Surabaya, 2000.

[2] G. Bruno, A. Genovese, C. Piccolo, and C. Sterle, "A Location Model for the Reorganization of a School System: The Italian Case Study," Procedia - Soc. Behav. Sci., vol. 108, pp. 96-105, 2014.

[3] G. Câmara and A. Monteiro, "Spatial analysis and GIS: a primer," Rio de Janeiro, 2009

[4] M. M. Al-Enezi, "A Study of the Relationship Between School Building Conditions and Academic Achievement of the Twelfth Grade Students in Kuwaiti Public High Schools," Virginia Polytechnic Institute and State University, 2002.

[5] J. A. Mhiliwa, "The Effects of School Location on Learner's Academic Performance: A Case Of Community Secondary Schools in Makambako Town Council, Njombe," Open University of Tanzania 2015.

[6] Z. Xinli and W. Qin, "Analysis of Industrial Agglomeration in Shaanxi Province Based on," Adv. Soc. Sci. Educ. Humanity. Res., vol. 213, no. Ichssr, pp. 313-318, 2018.

[7] W. Yan, "Rural School District Enrollment and Building Capacity," Pennsylvania, 2009

[8] J. Hallak, Planning The Location of Schools. Paris: The United Nations Educational, Scientific and Cultural Organization, 1977.

[9] H. S. Yunus, Research Methods of Contemporary Region. Yogyakarta: Pustaka Pelajar, 2017

[10]B. Y. Tiftikcigil, "An assessment on activities of regional development agencies in Turkey," Int. J. Econ. Financ. Issues, vol. 5, no. 2, pp. 399-409, 2015.

[11]Y. Avsar and M. T. Gonullu, "Determination of safe distance between roadway and school buildings to get acceptable school outdoor noise level by using noise barriers," Build. Environ., vol. 40, no. 9, pp. 1255 1260, 2005.

[12]R. Capello, "Location , Regional Growth and Local Development Theories," Aestimum, vol. 58, pp. 1-25, 2011.

[13]W. Dong, "Analysis on the Influence of Transportation Infrastructure on Manufacturing Agglomeration in Different Regions Weimin Dong," Adv. Soc. Sci. Educ. Humanit. Res., vol. 213, no. Ichssr, pp. 20-26, 2018.

[14] M. Moseley, Accessibility: the rural challenge. London: Methuen \& Co Ltd, 2017.

[15]A. Szajnowska-Wysocka, "Theories of regional and local development - Abridged review," Bull. Geogr., vol. 12, no. 12, pp. 75-90, 2009. 